\title{
A THEORETICAL-PRACTICAL ANALYSIS OF PHILOSOPHICAL AND PSYCHOLOGICAL ASPECTS OF HUMAN RESOURCES MANAGEMENT
}

\begin{abstract}
The article presents the role of human resources (HR) management philosophy in the work of an organization. The staff management philosophy development phases, the principles and functions are observed. The link of HR management philosophy with the socio-cultural traditions and different countries and ethnic groups is shown based on the analyses of HR management national peculiarities. The author also represents the specifics of the HR management process in law enforcement bodies and in the Police of the Republic of Armenia in particular. The socio-psychological specifics of HR management in the Police, as well as the perspectives of their development, are outlined.
\end{abstract}

Keywords: HR management philosophy, organization mission, Police personnel, ensuring the psychological aspect, personal quality, HR management tools.

Introduction

It is known that each sphere of knowledge, having reached a certain level of development, requires giving a meaning to its object, methods, principles and concepts and defining its specific place among the other sciences. This also happened to the field of management which having a huge history and shocking the world with the greatest creations of men by organizing the construction of the Egyptian Pyramids and the Hanging Gardens of Babylon developed into science only at the end of the $19^{\text {th }}$ century and the beginning of the $20^{\text {th }}$ century.

The definitions of the phenomenon of the "scientific management", the main laws and principles were first used in the works of $\mathrm{F}$.
Taylor, G. Emerson, G. Ford, H. Fayol ${ }^{1}$. In the book entitled "The Principles of Scientific Management" F. Taylor (1911) justified his thesis on the new perception of industrial enterprise management. The staff management theory developed along with the development of management science since every managerial science comes into existence where the human factor emerges in management. Later the empiric knowledge in the field of management obtained a more organised nature and transformed into a logical system of principles and methods. This development was the result of the application of achievements of several related sciences, such as Economics, Sociology, Psychology, Anthropology, Ethics, Social Philosophy, Philosophy of

\footnotetext{
1 For more details on scientific management or HR management theory formation, please refer to Fayol, Emerson, Taylor, \& Ford, 1992, p. 349.
} 
Culture, etc. That is why management science has an interdisciplinary character.

The management styles brought forward by $\mathrm{K}$. Lewin, the works on the activities of law enforcement bodies and personal qualities of employees of $\mathrm{Yu}$. Chufarowski, G. Shikhantsov, V. L. Vasiliev, the staff management psychology of O. V. Yevtikhov, etc. were studied given that ensuring the psychological aspect of the HR management process in the RA Police was considered important in the article. The research methods applied were the traditional analysis of documents, in-depth interviews, and focus group inquiries.

\section{The General Description of HR Management Philosophy}

HR management philosophical analysis is targeted at the study of human resources activities in the management process. In the work of V. S. Diev (2010), the management philosophy is defined as "a system of generalising judgements of philosophical character on management methods and its object, the place of "management" among other sciences, its gnoseological and social role in the contemporary society" (pp. $35-41)$.

The management philosophy is to bind the sense of the organization existence with the sense of the work of the employees working there in order to find agreement and harmony. For this reason, the sense of HR management philosophy is to achieve harmony in relations between the employee and the manager. In fact, philosophy in the field of HR management presumes how the management treats its employees, what role they play in the success of their work, how they should communicate with them and how to manage them.
According to M. U. Rogozhin (2008), the HR management philosophy is perceived as a system of organization/enterprise management views and ideas on the essence of staff management as a specific type of management activity (p. 11).

HR management philosophy defines a priority system in the process of organising the HR management, including the attitude both to the whole staff and to each employee individually. Thus the HR management philosophy includes the principle of the flexible attitude in which the employee is a valuable asset. This all creates sound competitiveness, not on account of HR management, but of each employee's commitment to the company/organization assets. For this reason, from our viewpoint, it is very important to include the interests of both the company/organization and each employee in organizing the management process efficiently.

HR management philosophy, first of all, is targeted at findings of relations between the company/organization and the employee. Giving each employee an opportunity to meet his/her needs during the work, the organization manager can develop the company. The HR management accepted in the company allows ensuring equal, fair, mutually beneficial relations, to develop trust not only between the employees and managers but also between the consumers, stakeholders and suppliers. As a consequence, HR management philosophy creates an opportunity to not only present the moral-ethical basis of the company/organization activities analytically but also to contribute to stabilizing the sound sociopsychological atmosphere.

R. Shuler speaking of HR management philosophy issues came to the following conclusion: "...HR management philosophy defines how the companies/organizations treat their hu- 
man resources, which aims the resources pursue in the overall work success and how they should be treated and managed. HR management philosophy defines guidelines that are necessary for the development of HR management projects and issues related to people emerging in the field of work, as well as for the development of practical methods for organizing the work based on strategic goals" (Randall \& Dennis, 2004, p. 284). On the whole, philosophy allows reviewing management from outside penetrating into the essence of the management activity. The HR management philosophy is conditioned by objecttive and subjective factors, as well as by the external and internal environment.

The political and economic situation of a country that dictates its rules in the company/ organization management is classified among the objective factors. And the subjective factors refer to the viewpoints of the owners, founders and chief executives on management, strategy, as well as the prescribed period of this company's operation in which it is currently.

Efficient HR management immediately influences the stability of the company/organization. This is particularly displayed in crisis situations. The change of the external environment influences not only the managerial decision making of the leadership but also the staff behaviour. If a system known to everyone functions in a company, this allows to overcome hardships, make the right decisions.

It is known that the organization mission is the main goal of its operation, the reason for and the sense of its existence. The mission and philosophy are mutually conditioned. The sense of the existence of successful organizations is in their social direction. In case of orientation on exclusively corporative values, the organization loses its viability and may stop its existence under the influence of the competition. As it is mentioned in professional analyses, if the goals of an organization become the goals of every single employee, he/she will make maximum efforts for their implementation (Genkin, 1999).

In another research, P. Druker (2007) wrote that it is better not to manage people at all, but to guide them instead, this is about developing partnership relations between employees. There should be trust in the basis of communication with an employee. Only then the employees will strive to work selflessly, committed and will make "sacrifices" to the company. Then the main principles will be loyalty and mutual trust. Highly appreciating the selflessness and commitment in working relations, we consider it necessary to touch upon the fact that commitment cannot be the only component of partnership relations and very often it is not enough as a condition for the efficient operation of the organization.

In the context of the HR management philosophy of a company/organization, the employees are viewed as the main asset and not an investment base, which consequently is grounded on certain principles:

- following the labour legal framework;

- justice;

- absence of discrimination;

- a decent attitude to a hired employee as the most important resource for the implementation of strategic and tactical goals.

The following idea can be cited as an example of an application of principles of working with human resources in the Russian professional literature "...the principles are as follows in the field of work with staff: employees can count on stable salaries if a vacant position for a manager is open, the preference is always given to the employees of the institution, in the case when the relations between the employer and 
employee are built on the basis of partnership relations" (Kibanov, 2010, pp. 87-88).

HR management philosophy existence gives the company/organization an opportunity to have an additional impact on the organization management process. This can be reached due to the unified system of the "game rules" in the organization for the employees and for the organization in general. When the employees clearly realize their mission in the organization, they know the principles on which their own conduct inside and outside the organization should be based.

The organization strives to have such staff that agree to its philosophy and established values. Those who do not accept these values don't have any perspective to work in this organization.

The following functions of the organization philosophy are marked out in A. Ya. Kibanov's (2010) works:

- product of solidarity;

- development of special orientations in the staff conduct and activities;

- forming a deep understanding of the activeties of each employee and administrative subdivisions;

- creating a consistent and recognizable image of the company in the external environment (pp. 96-97).

It is necessary that the HR management humanistic value system is institutionalized so that the organization ensures these principles. As a result, it is often formulated in the form of a separate document that permits clearly regulating the relations between the employees and the management. The existence of a normative document contributes to adaptation of new employees to the existing system, to clearly conduct the per- sonnel policy, to organize the staff interrelations, etc.

The HR management philosophy fixed in a document gives the opportunity to establish just, reliable relations among the team, to raise the role of employees in decision-making processes, to improve the working life quality. The violation of the principles mentioned above can result in a conflict between the administrative team and employees and can bring to the collapse of the organization.

According to the opinion of numerous specialists, the philosophical bases of the organization activities were first clearly formulated in Japan. Akio Morita (1990) developed the HR management philosophy of the company Sony: "if it were possible to create conditions in which people could unite for a clear goal of working together and applying their technics, their abilities to make their own dreams come true, then such an organization could cause both a great pleasure and a great benefit".

In Japan, the model of "Our wealth is the human resources" which corresponds to the idea of "The Company is our family". The HR management practice of Japan is directed at ensuring employment during the whole working life. The social difference among the employees is not significant. The work management is implemented through a group principle in which the responsibility for the work quality and result is taken by the whole group.

Thus, summing up the above-mentioned we come to the conclusion that the HR management philosophy also has a vividly expressed national, socio-psychological belonging.

Certain peculiarities of HR management in the context of the Police of Armenia will be presented below. 
Certain Psychological Peculiarities of

\section{HR Management}

When touching upon the psychological side of HR management, we should mention that the process of reforms taking place in the law enforcement system in the Republic of Armenia creates favourable conditions for the development of the HR management system in the RA Police. Parallel to the quick changes in management styles and principle happening in the law enforcement system and in the whole republic, the study of the socio-psychological peculiarities of the management activities grows into a necessity.

The concept of HR in the field of psychology is used quite often, but unlike the field of philosophy, it is not completely developed yet, and these resources as a factor to regulate the emotional state is poorly studied (Bodrov, 2000, p. 223). The main goal of the HR management function in each organization is to confirm the most efficient use of HR (Bas, 2010).

What is meant by "ensuring the psychological aspect in the HR management" is the personnel activities management, a series of psychological preconditions, issues that are solved by special psychological technologies and are the ensuring of localisation of the operating system in the country (Kabachenko, 2003, pp 1820).

Speaking of the RA Police HR management process, it should be mentioned that on 16-20 December 2019 a focus group discussion targeted at finding the socio-psychological issues of HR management efficiency among the RA Police personnel was held by the Education Quality Assurance Department in the RA Police
Educational Complex ${ }^{2} .10$ managers of the Complex departments and 6 representatives of the RA Police managerial personnel took part in the discussion.

Having summed up the results of the research carried out, the findings as sociopsychological issues related to HR management in the Police are as follows:

- The RA Police has a mixture of military hierarchy/ranks classification system and the Police civilian staff approach, which means that the career of the employee is mainly determined by meeting certain military rank standards, which in its turn is a mandatory precondition for taking up the position. Today we cannot see any administrative instruction (with the exception of law) that defines the standards of different ranks but, as it was found out during our meeting when getting employed by the RA Police, the employee can rarely avoid getting a rank. This situation makes it difficult to foster the appointment of young and reform-tended specialists in managerial posts internally in the current system in order to break the obstacle of changes in the middle managerial circle.

- There is no HR management policy sufficiently developed in the RA Police, which can clearly show the scope of the "new police". The Police reform strategy document completes it to some extent, but it contains very little materials on the Police personnel quality necessary changes or the responsibilities of the police during the contemporary public service. Here it is noteworthy that the conceptual changes of the Police traditional role and mission present

2 The research was held with 16 participants of the focus group on 16-20 December, 2019. 
totally new requirements for the Police conduct and personal qualities considering independence, responsibility, flexibility, tolerance, communication skills, psychological proficiency, etc. more significant. The vagueness of the HR management general policy was expressed in different ways by other organizations as well, the most recent ones being the OECD SIGMA in the Baseline Measurement report of which in March 2019 a general recommendation on Armenia was provided to the RA Government "to make changes in the legal framework on civil service which clarifies the civil service horizontal scope in regards with the positions in the customs office, tax administrative staff, intelligence service departments, diplomatic service and law enforcement bodies" 3 .

- The RA Police does not possess any contemporary tools that would fully correspond to the general goals of the Police for assessing the personnel's personal qualities, e.g. what can/should the officer/department do to support the Police reforms. Still, the idea that the Police or policemen cannot do much to change the system and that the orders so-to-say "come from above" is still there. As a result, the training of the junior Police personnel has a rather low demand which does not allow to ensure any professional or personal growth. And as it is known the efficiency of the work of an employee- of a policeman in this case, is mostly conditioned by the professional motivation that includes the person's needs, ambitions, interests, biases, believes, posi-

For more details see Public Management Principles "Baseline Measurement Report", Armenia, March, 2019, http://www.sigmaweb.org/publications/Baseline-Measurement-Armenia-2019-ARM.pdf. tions and so on. The psychological aspects of motivation are the most important personal characteristics of a policeman, the person's attitude to the environment, and being expressed in the motives, and it is displayed in actions, conduct, gets strengthened through them and becoming usual evolves into relatively stable features of a character and qualities ${ }^{4}$.

Considering all the aforementioned, we think that the possible input of HR management tools in the RA Police may correspond to the reforms planned by the RA Ministry of Justice, namely to e-management initiatives. In addition, in the scope of the RA management wider reforms, there can be already developed HR management systems, and that can ease the modern personnel policy input into the RA Police.

\section{Conclusion}

Thus, it has now become topical to input HR management clear systems to assist the HR planning and career development, and it will be appropriate to link the input of the systems with the overall IT support of the country at the same time challenging us to disclose personal qualities and necessary functions for professional success that dare not subject to the operation fall because of a long-lasting and tense professional influence or in case of a change of working tools. And from the philosophical viewpoint, the development of HR management philosophy gives the opportunity to ensure equal rights, fair relations, a comfortable moral-psychological atmosphere, social security of employees, employees' participation in decision-making processes in the or-

4 For more details on the Interrelation of a person's motivation and character formation see Rubinstein, 2000, p. 712 . 
ganization and also ensuring the moral-ethical basis of the activities of the company.

\section{REFERENCES}

Bas, V. N. (2010). Metodologiya upravleniya organizatzionnim povedeniem na osnove korporativnoi kul'turi $v$ sisteme upravleniya personalom (Methodology of Managing Organizational Behavior Based on Corporate Culture in the System of Personal Management, in Russian) (Doctoral dissertation). Moscow: 99 Ryazanskiy Prospekt, Scientists' Council conference hall. Retrieved November 28, 2019 from: https://www.dissercat.com/content/metodolo giya-upravleniya-organizatsionnympovedeniem-na-osnove-korporativnoikultury-v-siste/read.

Bodrov, V. A. (2000). Informatzionnyi stress, uchebnoe posobie dlya vuzov (Informational Stress, textbook for high schools, in Russian). Moscow: PER SE.

Diev, V. S. (2010). Upravlenie, Philosophiya, Obshestvo (Management. Philosophy. Society, in Russian), Philosophy Issues, 8, 35-41.

Druker, P. F., (2007) Zadachi menedzhmenta v XIX veke (Management Objectives in the Nineteenth Century, in Russian). Moscow: Vilyams.

Fayol, H., Emerson, G., Taylor, F., \& Ford, G.
(1992). Management is a Science and Art. Moscow: Respublica.

Genkin, B. M. (1999). Ekonomika i sotsiologiya truda (Economics and Sociology of Labor, in Russian), Textbook. for universities (2nd ed). Moscow: Norma; Infra.

Kabachenko, T. S. (2003). Psikhologiya v upravlenii chelovecheskimi resursami: $U$ chebnoe posobie (Psychology in Human Resource Management: Textbook, in Russian). Saint Petersburg: Peter.

Kibanov, A. Y., (2010) Upravlenie personalom organizatzii (Organization HR Management, in Russian). Moscow: Infra-M.

Morita A. (1990). Sdelanno v Yaponii: Istoriya firmi Sony (Made in Japan: The History of the Company "Sony", in Russian). Moscow: Progress.

Randall, S. S., \& Dennis, R. B. (2004). International Human Resource Management, $2^{\text {nd }}$ ed. New York: Routledge.

Rogozhin, M. Y. (2008). Upravlenie personalom (HR Management, in Russian). Moscow: Prospect.

Rubinstein, S. L. (2000). Osnovi obshei psikhologii (The Basics of General Psychology, in Russian). Saint Petersburg: Peter.

Taylor, F. W. (1911). The Principles of Scientific Management. New York, London: Harper \& Brothers. 